\title{
A People of One Book: The Bible and the Victo- rians, by Timothy Larsen
}

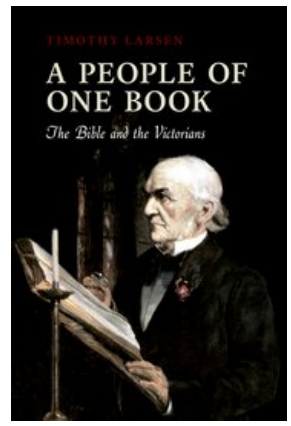

Oxford: Oxford University Press, 20 I I 326 pages | ISBN: 978o-19-957009-6 (hardcover) $£ 34.00$

The Victorians read the Bible-prolifically. This is the thesis of the book, and one fulsomely demonstrated. But even though the case for the novelty of this thesis is made out in the introduction, it probably won't come as a surprise to any who have even a passing acquaintance with the period, admitted as such by the writer himself: "no one has ever doubted that the Bible had a prominent place in Victorian culture" (295). The point of the book therefore is really to demonstrate how much the Bible held a prominent place, across a wide range of groups and individuals, from atheists (such as Charles Bradlaugh) to Catholics (such as Cardinal Wiseman), from agnostics (self-defined by Thomas Huxley) to Quakers (such as Elizabeth Fry). Here gathered into one book are a series of case studies ultimately built on the refrain that so- 
and-so was a Bible man/woman. And this is one of the welcome features of the book; that is, the determination to ensure that the majority of church attenders - women - find significant representation in the case studies, half in fact.

There is no particular logic in the order, with Timothy Larsen claiming that arrangement was determined by the unfolding chronology of his research (7). He actually had dreamed of including more- the Brethren, Jews and Spiritualism-but the exigencies of publishing determinations prevented anything more than summary pages tacked into a concluding chapter. I was particularly disappointed that a Jewish presence was not included, not merely because his designated representative, Grace Aguilar, is so intriguing in her deft self-positioning in the values and culture of Victorian society, but also because Jewish biblical scholarship was beginning to be touted in public and private arenas. So, for example, the House of Commons MP Charles Buxton wanted Jews invited into the committee for the revision of the KJV Old Testament. Even though Gladstone stymied this appeal, members of the both Old and New Testament committees did turn to various London rabbis for advice. As for the Spiritualists and the use of the Bible, this section could have been, strangely perhaps, dove-tailed into Annie Besant who moved from atheism to theosophy, perhaps wedding her with Robert Owen rather than Charles Bradlaugh. As for the Brethren, the repetition of the separation of Victorian indebtedness to the Bible from those embroiled in "higher criticism" might have been tempered somewhat by the mention of the groundbreaking significance of the text-critical work of Samuel Tregelles. His was a special relationship with the Anglican Fenton J. A. Hort. Hort took the responsibility of seeing Tregelles's textual work on the New Testament through to completion after first his health, then sight, then ultimately life faded.

This relationship belies a number of loose assumptions that drop into the text from time to time- that Broad Church (with which Hort was generally equated) and skeptical are to be combined together as if both were interested in destroying the Bible. And yet, in other places, there is some greater precision granted, for example where Broad Church is defined ( I I 4) and separated from "liberal" (222). The problem is not only that such terms seem loosely applied, with occasional greater precision fostered by the requirements of a particular case-study, but other terms are dropped in as if they capture the meaning of a nineteenth-century position. It is simply misleading to speak of F. D. Maurice and Charles Kingsley as "even post-Christian thinkers" (223). In this sense, the author at times seems merely to reinscribe attitudes held 
by some groups in the period, even though they may be given the added incitement of contemporary terminology. Occasionally also, Larsen speaks for his subjects, claiming for example that Besant would have destroyed a paper (75-76), or "Pusey would have deferred to Keble as the true father" (I2) or even "As a theological liberal, Nightingale also wrote sermons" (I29). These sort of throw-away comments may be fit for a student lecture but bedevil historical writing by putting words into the mouths of the past with no chance of their subjects' rejoinder.

The fundamental problem for the book lies in its very case-study approach that is adopted. There is an absence of coherent methodology for analysis. This begins with the problems of trying to decide what "representative" means for particular individuals. How is Mary Carpenter for example to be taken as representative of Unitarians in their approach to the Bible, especially when G. Vance Smith is invited into the New Testament committee for the work of the Revised Version-an invitation gratefully accepted as marking a recognition of the learnedness of Smith and a measured acceptance of his biblical scholarship amongst an array from Methodists to Baptists. The defence of Florence Nightingale as "representative" of "Liberal Anglicans" reaches apologetic dimensions (I I4) when Larsen argues that because men such as J. W. Colenso and F. D. Maurice were ordained they were "restrained by clerical subscription and ministerial propriety and effectiveness from being too bold in their speculations and pronouncements." That both men paid for their boldness of pronouncement is clear from the historical record, with Maurice at least being regularly touted as having an immense influence on two generations of Anglicans, spinning off in different directions. This is not to deny Nightingale's inclusion but the justification is over-wrought. Indeed, it would have been an interesting study to plot the lines of influence between the Reverend Benjamin Jowett and Nightingale's ideas, for he too paid a heavy price for his contribution to the infamous Essays And Reviews and avowed thereafter to restrict himself to exposition of the classics, especially Plato.

This leads to a further issue of method. It is one thing to assert that the Victorians were "People of One Book." It is another to test that assertion by countervailing evidence. In one sense the Victorian period was equally a Hellenising or Classicising period as it was a biblicising one. This shows out in one quotation from Nightingale herself. The array of alternatives to some less-favoured and -favourable biblical stories come from the Classics Achilles and his horses, Andromache and Antigone with Homer, Sophocles 
and Aeschylus the great suppliers of great lore ( $132-3)$. The array is no coincidence. As Richard Jenkins noted, "Few people suspect the extent to which the ancient world, and especially Greece, influenced the Victorians.... Unless we realize how much the Victorians thought about Greece we will not fully understand them" (The Victorians and Ancient Greece, $\mathrm{x}$ ). As if to accent this observation, the cover of the book, with the avowed King James supporter, William Gladstone reading from the Bible lectern at St. Deiniol's Anglican Church, Hawarden, finds no echo in the book, with Gladstone scoring but two asides. For all his devotion to and formation in the language of (KJV) Bible English, he yet extols "that wonderful thing Hellenism," as well as being a member of the Society for Psychical Research. Yes, Victorians were saturated in the Bible and biblical language but they were also saturated in many other aspects that have been seen as characterizing the age. It is how the Bible was held together with these other aspects, informing and informed by them, that complicates the picture of the Victorians and the Bible. It is simply not helpful to assert as a concluding insight that the Anglo-Catholic Pusey was "a Bible man" (4I) and that the first Roman Catholic archbishop of Westminster, Nicholas Wiseman "was a Bible man all his life" (56), or again "a Bible man through and through" (65). Even allowing that one was an exegete and another a textual scholar does not open up interpretative insight into the array of assembled material.

The subtlety of the explorations of how the Bible was meaningful, not simply that it was, that one finds in, say, Stephen Prickett's Words and the Word or Michael Wheeler's two volumes on John's Gospel (Death and the Future Life, St John and the Victorians) is what goes begging in this catalogue of case studies. Having noted that two of the women (at least: the Quaker Elizabeth Fry and Nightingale) annotated their Bibles with references to their own personal lives and to public events, one is left wondering what self-definition, -therapy, -justification was operating here and how the Bible was being used to shape understanding and directions. Larsen's penchant for lists (see, for example, $2 \mathrm{I}, 37-38,39,40$ ) in spite of a recognition that such cataloguing can become tedious (80), may be useful in the fodder for analysis but it is the analysis that becomes critical. Otherwise, one is in danger of reinscribing biblicist attitudes as a screen of deeper matters that are being explored. One thinks, for example, of the use of the Bible as the arena by which denominations and even nations staked their claims for status and recognition. Conversely, one sees the fracturing of denominational lines as between the Anglican Brooke Foss Westcott and the Methodist William Moulton as they 
joined together in common tasks that bonded them in friendship throughout their mature lives.

The book does re-awaken a sense of the richness of the material that can be harnessed to investigate and fill out the case that the Bible was much-used, much-loved by the Victorians, even that it was a, if not the, major linguistic provision for imagining their world. The period was a time when letters, books, speeches, and lives were treasured, thereby providing a vast reservoir of evidence from which to drink - the list of manuscripts, magazines, and contemporary printed material at the end of the book bear powerful witness to this. What Larsen's book has achieved is a reminder of that resource. The development of a coherent method of analysis of that resource, in part along the lines suggested by Prickett and Wheeler, yet remains.

Alan Cadwallader Australian Catholic University 